\title{
Sensory Evaluation of Different Packaged Roast Beef Treatments Designed for the Extension of Its Shelf Life
}

\author{
Tamador Maaya ${ }^{1}$, Basem Mohammed Al-Abdullah ${ }^{2}$ \\ ${ }^{1}$ Risk Management Unit at Jordan Food and Drug Administration, Amman, Jordan \\ ${ }^{2}$ Faculty of Agriculture, University of Jordan, Amman, Jordan \\ Email: Tamador.maayah@jfda.jo, Basem@ju.edu.jo
}

How to cite this paper: Maaya, T. and Al-Abdullah, B.M. (2016) Sensory Evaluation of Different Packaged Roast Beef Treatments Designed for the Extension of Its Shelf Life. Food and Nutrition Sciences, 7, 1052-1061.

http://dx.doi.org/10.4236/fns.2016.711101

Received: April 19, 2016

Accepted: September 25, 2016

Published: September 28, 2016

Copyright $\odot 2016$ by authors and Scientific Research Publishing Inc. This work is licensed under the Creative Commons Attribution International License (CC BY 4.0).

http://creativecommons.org/licenses/by/4.0/

\section{Abstract}

This study was carried out to investigate the effect of different nitrite concentrations on the sensory parameters of roast beef including color, flavor, juiciness, texture and overall acceptability. Four roast beef batches were formulated; the first three treatments were with nitrite concentrations of $0.006 \%, 0.012 \%$ and $0.018 \%$ and stored at abused chilling temperature $\left(12^{\circ} \mathrm{C}\right)$, while the fourth one was a control treatment with $0.026 \%$ nitrite and storage at $4^{\circ} \mathrm{C}$. Results showed that increasing nitrite concentration from $0.006 \%$ to $0.026 \%$ enhanced the shelf life of roast beef stored for 7 days without affecting the sensory characteristics whether at $12^{\circ} \mathrm{C}$ or $4^{\circ} \mathrm{C}$ since there were no significant differences $(\mathrm{P}>0.05)$ between all treatments regarding color, flavor, juiciness, texture and overall acceptability. These results could direct us to use high nitrite concentration to protect this product and elongate its shelf life without affecting its preference parameters.

\section{Keywords}

Roast Beef, Nitrite, Chilling Temperature, Shelf Life, Sensory Evaluation

\section{Introduction}

Roast beef is a cured, cooked, and smoked whole meat piece product. It is usually consumed or served cold after processing. As roast beef is a cured meat product, curing contributes to the characteristic pink color, specific texture and flavor, and provides a preservative effect especially against the growth of spores of Clostridium botulinum [1] [2].

Nitrite is a critical component used to cure meat [3] [4], and to reduce the growth rates of pathogens such as L. monocytogenes, E. coli O157:H7, S. aureus, and Bacillus 
cereus at levels used in cured meat and poultry products [5]-[9]. The antioxidant effect of nitrite is likely due to the same mechanisms responsible for cured color development involving reactions with heme proteins and metal ions, chelating of free radicals by nitric oxide, and the formation of nitroso- and nitrosyl compounds having antioxidant properties [10].

In order to keep meat products safe through the food chain, sodium nitrite is most commonly used in meat curing to help develop a desirable flavor and attractive color. Nitrite retards the development of meat rancidity and unpleasant flavors and odors of meat during storage [3]. Many researches were carried out to investigate nitrite alternatives in a step to complete or partially substitute its use in meat and meat products [11]-[18]; they concluded that complete nitrite replacement is not possible but partial replacement in combination with other additives which is acceptable.

Most of the added nitrite during the product manufacturing is either depleted through a series of reactions or lost during certain manufacturing steps. Typically, between 10 and 20 percent of the originally added nitrite normally remains after the manufacturing process and those levels continue to decline during storage. These levels of nitrite, referred to as residual nitrite, slowly decline over the storage life of cured meat products until they are often non-detectable [4] [19].

Therefore, we carried out the first part of this research to investigate the effect of different nitrite concentrations and chilling temperature on the shelf life and chemical parameters of the studied roast beef [20] and we found that roast beef containing $0.026 \%$ nitrite and stored at $4^{\circ} \mathrm{C}$ for 25 days had the lowest thiobarbituric acid (TBA) values, microbial growth and the lowest percentage of nitrite losses during storage.

As the sensory evaluation is one of the main shelf life parameters, therefore, the objective of this study was to:

- Evaluate the effect of different nitrite concentrations on the sensory parameters of the studied roast beef including color, flavor, juiciness, texture and overall acceptability.

\section{Materials and Methods}

\subsection{Roast Beef Manufacture}

Frozen raw beef topside was taken out of the freezer and tempered overnight. The meat blocks were cut into pieces of $10 \mathrm{~kg}$. It was then transferred to the brine injector where the injector delivers a solution of salt, sodium nitrite, potato starch, isolated soy bean protein, sodium ascorbate, sodium tri-poly phosphates, spices and water (Table 1).

The mixture was cooled to a temperature of $4^{\circ} \mathrm{C}$. After injection, the beef were transferred to the tumbler, which is also cooled down to $4^{\circ} \mathrm{C}$. The tumbling process took about one hour under vacuum pressure. Then, the meat pieces were placed into fibrous packages, and the packaging process took place under vacuum, and was controlled by computer, each bag contained $1 \mathrm{~kg}$ of meat. The beef, then, was held for certain time at about $6^{\circ} \mathrm{C}-7^{\circ} \mathrm{C}[21]-[23]$. 
Table 1. Meat and brine formula used to produce roast beef.

\begin{tabular}{ccccc}
\hline \multirow{2}{*}{ Ingredients } & \multicolumn{4}{c}{ Treatments } \\
\cline { 2 - 5 } & A & B & C & D \\
Meat (kg) & 10 & 10 & 10 & 10 \\
Water (L) & 7 & 7 & 7 & 7 \\
Salt (\%) & 7 & 7 & 7 & 7 \\
Sodium tripolyphosphate (\%) & 2 & 2 & 2 & 2 \\
Sodium ascorbate (\%) & 0.3 & 0.3 & 0.3 & 0.3 \\
Sodium nitrite \% & 0.006 & 0.012 & 0.018 & 0.026 \\
Potato starch (\%) & 5 & 5 & 5 & 6 \\
Soybean isolate (\%) & 6 & 6 & 6 & 0.9 \\
Spices (\%) & 0.9 & 0.9 & 0.9 & 17 \\
Total (kg) & 17 & 17 & 17 & 5 \\
\hline
\end{tabular}

\subsection{Cooking and Storage}

Roast beef batches were thermally processed in a steam oven as follows:

The beef in their special fibrous bags was dried for 40 minutes to lower the amount of water. Following drying, the beef was liquid smoked at $76^{\circ} \mathrm{C}$; smoking took 1.30 hour, then the beef was dried for 3 minutes. The roast beef was cooked to a core temperature of $74^{\circ} \mathrm{C}$ for 4 hours. After cooking the beef was allowed to dry to get the roasted color. Then the beef was taken out to be cooled in the blasted chiller for four hours, to cool from $64^{\circ} \mathrm{C}$ to $1^{\circ} \mathrm{C}$. After that, the roast beef was kept in refrigerator at $4^{\circ} \mathrm{C}$ throughout the duration of the experiment D. B, C and A samples were taken and kept at abused temperature $\left(12^{\circ} \mathrm{C}\right)$.

\subsection{Proximate Analysis}

Moisture, fat and protein were determined directly after storage using Infratech Analyzer (Model Tecator 1265, Sweden) [24]. Ash determination was carried out according to AOAC [25].

\subsection{Sensory Evaluation}

A hedonic scale test as described by [26] was used to investigate the degree of preference to the roast beef treated with different levels of nitrite and different chilling temperatures after seven days of storage. The four treatments were evaluated in one session. Thirty five panelists were chosen from the teaching staff, graduate students and technicians of the Department of Nutrition and Food Technology, University of Jordan. The panelists were from both sexes, and from different ages, they were requested to taste each sample separately without comparing it with other samples. These panelists were familiarized with the questionnaire of the sensory parameters. The samples were evaluated for desirability in color, flavor, juiciness, texture and overall acceptability us- 
ing a 9-hedonic scale test, varying from 9, which means like extremely to 1 , which means dislike extremely. Pieces of bread and water were used to neutralize the taste between samples testing.

\subsection{Statistical Analysis}

Statistical analysis of data was carried out using Statistical Analysis System (SAS) package. Analysis of variance (ANOVA) of the general linear models (GLM) procedure of statistical analysis system was used. The significant differences between means were determined at $\mathrm{P}<0.05$ using Duncan Multiple Range Test. Correlation coefficient was used to estimate the interaction between different measures were generated using the Pearson's correlation coefficient [27] [28].

\section{Results and Discussion}

\subsection{Proximate Composition}

Proximate contents of the roast beef were $78.4 \%$ moisture, $1.8 \%$ fat, $14.8 \%$ protein, and $3 \%$ ash. This similarity in proximate is due to the use of the same components as well as cooking program for all treatments except of nitrite concentration as shown in Table 1.

\subsection{Sensory Evaluation}

The sensory characteristics of color, flavor, juiciness, texture and overall acceptability were evaluated using 9-hedonic scale. There were no significant differences $(\mathrm{P}>0.05)$ between all treatments. When the roast beef Samples were compared with each other, the panelists were unable to differentiate sensory differences, despite of different added nitrite levels. These results indicate that the ability to extend shelf life of the roast beef [20] without affecting the sensory properties which are considered one of the main shelf life parameters. Moreover, storage and distribution of this product through the food chain could be enhanced and become more flexible.

\subsubsection{Color}

Figure 1 shows the color scores of roast beef treatments. Although the added nitrite levels were different, a typical red cured meat beef color was achieved and scored in the range of "like slightly" to "like moderately". This could be due to that only small quantities of nitrite are required to produce the cured meat color: theoretically $2-14 \mathrm{mg} / \mathrm{kg}$ is sufficient to convert half of the myoglobin present in fresh meat, but more nitrite is required to provide for the competing reactions, and $25 \mathrm{mg} / \mathrm{kg}$ are required to give a stable cured color throughout the extended shelf life [29] [30]. Moreover, vacuum packaging could be considerably effective to increase the desirable meat color during storage [31].

Color scores are usually affected by nitrite level, but in our case, the insignificant difference in color could be explained by the fact that the magnitude of differences in color between samples was very little and the panelists were unable to detect it. Color is

one of the main food appearance attributes and has very significant role in the quality evaluation of meat and meat products as well as purchase decision [32] [33]. Therefore, 
it is beneficial to enhance other quality characteristics without affecting this significant parameter.

\subsubsection{Flavor}

The values of flavor scores for the different treatments as shown in Figure 2 were numerically close and not statistically different $(\mathrm{P}>0.05)$. There were no significant preferences between treatments regarding flavor and were scored as "like moderately". The effect of nitrite was much greater at the higher levels than at the lower levels of nitrite, in that the flavor was not significantly different between the different levels. These results are in agreement with those found by [34], so we can conclude that the amount of nitrite present $0.018 \%$ and $0.026 \%$ did not influence the flavor of roast beef. It was also indicated that nitrite has no effect in cured flavor development in all cured meat [12] [35]. On the other hand, [36] suggested that cured flavor may be a result of combination of complex nitrite-related flavor and aroma, and suppression of rancidity formation, since nitrite has antioxidant effect.

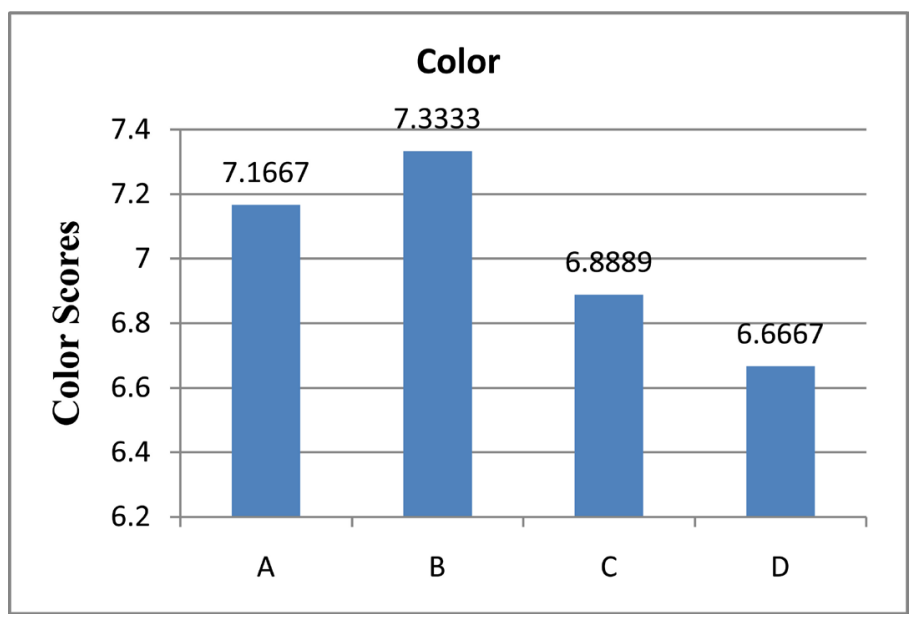

Figure 1. Sensory evaluation of roast beef color.

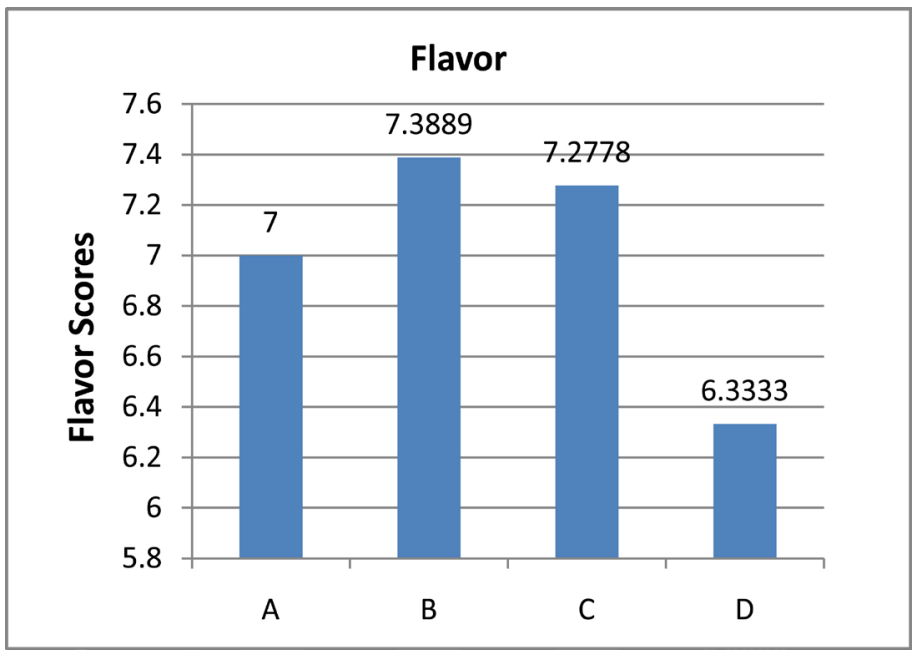

Figure 2. Sensory evaluation of roast beef flavor. 


\subsubsection{Juiciness}

As shown from Figure 3, the juiciness scores of the roast beef treatments were also not significantly different. There were no significant preferences between treatments which were scored as "like slightly to like moderately". The juiciness scores of all treatments were acceptable. Higher juiciness score was found in treatment A which contained $0.006 \%$ nitrite. The sensory scores indicated a decrease in juiciness in treatment $\mathrm{D}$ with $0.026 \%$ nitrite, but it was statistically insignificant $(P>0.05)$. [37] reported that juiciness is related to the type of meat used in the formulations, rather than the chemical composition when he evaluated the sensory properties of five canned luncheon meat formulations.

\subsubsection{Texture}

The texture of the roast beef that ranged from "like slightly" to "like moderately" (Figure 4 ) indicated that roast beef samples with $0.018 \%$ added nitrite had a softer texture than roast beef with $0.006 \%$ added nitrite. The inclusion of nitrite, at low level $(0.006 \%)$, seems to make the texture of roast beef more acceptable. Increasing the

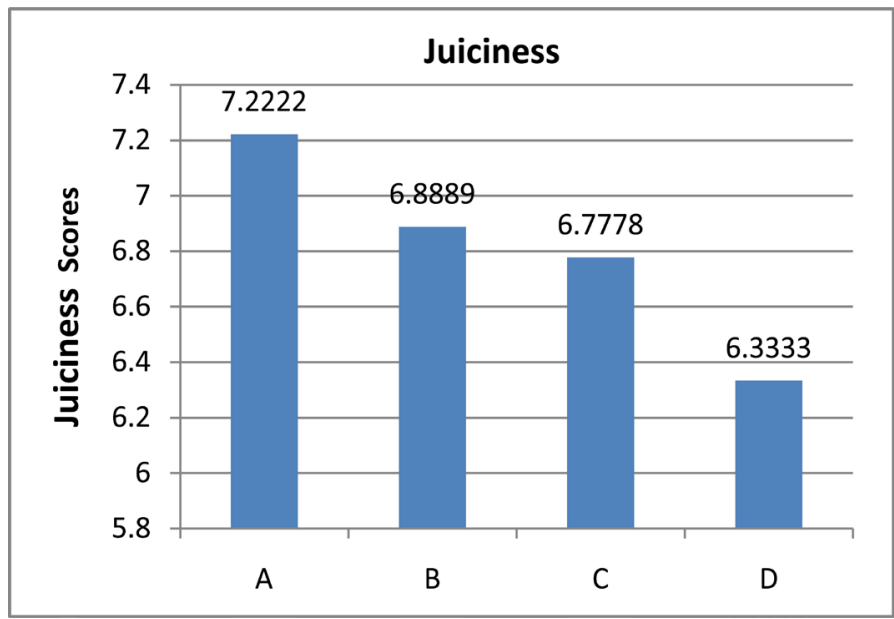

Figure 3. Sensory evaluation of roast beef juiciness.

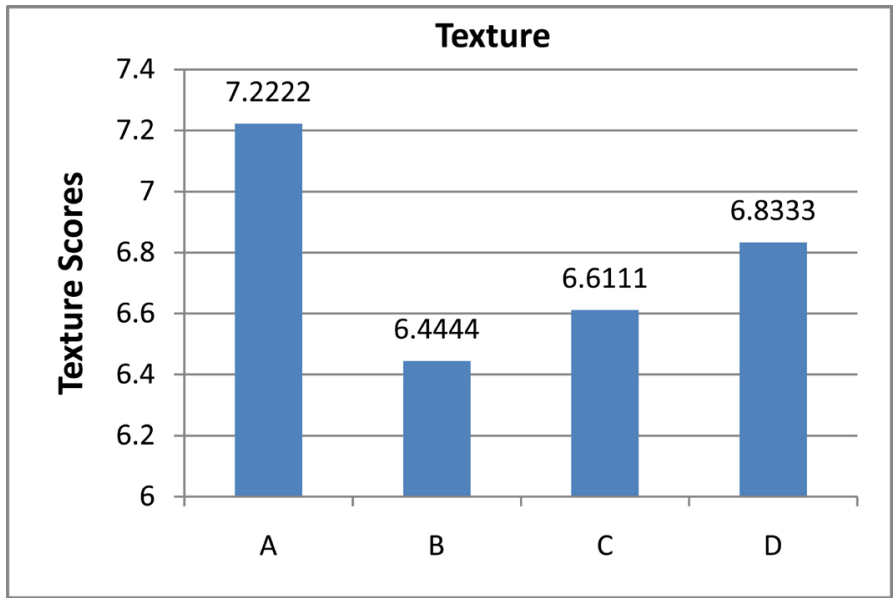

Figure 4. Sensory evaluation of roast beef texture. 
amount of nitrite from $0.006 \%$ to $0.018 \%$ had no additional effect on texture scores; it seems likely that nitrite curing affected the texture of the meat. That is in disagreement with [4] who reported that reactions between nitrite and myofibrillar proteins positively affected the texture of the cured meats.

[38] reported many factors that can affect the texture of meat products such as product formulation, fat and protein content and characteristics, and other factors. In our results tenderness as well as juiciness were not significantly $(P>0.05)$ different, this could be due to the using of the same formula for all treatments except of the nitrite concentration. This was demonstrated by the proximate analyses that were similar to the all treatments with no significant differences, which could be reflected on the textural characteristics of the treatments. [12] found that variations in nitrite concentration had no additional effect on the mortadella texture.

\subsubsection{Overall Acceptability}

Overall acceptability is the summation effect of the all sensory parameters, therefore, treatments that received high evaluation scores regarding their color, flavor, juiciness, and texture will be scored high as overall acceptability. The hedonic evaluation scores for overall acceptability corresponding to "like moderately" show that no significant $(\mathrm{P}>0.05)$ difference between all treatments (Figure 5), which might indicate that different nitrite levels do not affect the overall acceptability [34].

It seems that the panelists were unable to differentiate between treatments of the roast beef, and so, the results showed that high nitrite level of $0.026 \%$ did not cause any sensory differences. Meat is a perishable food, therefore, it is necessary to control meat spoilage in order to increase its shelf life, maintain its nutritional value and other quality and sensory parameters [39].

\section{Conclusion}

It could be concluded from the overall results of the sensory evaluation that different added nitrite concentrations have no significant effect on the investigated sensory characteristics, and the addition of $0.026 \%$ nitrite with proper refrigeration has resulted in

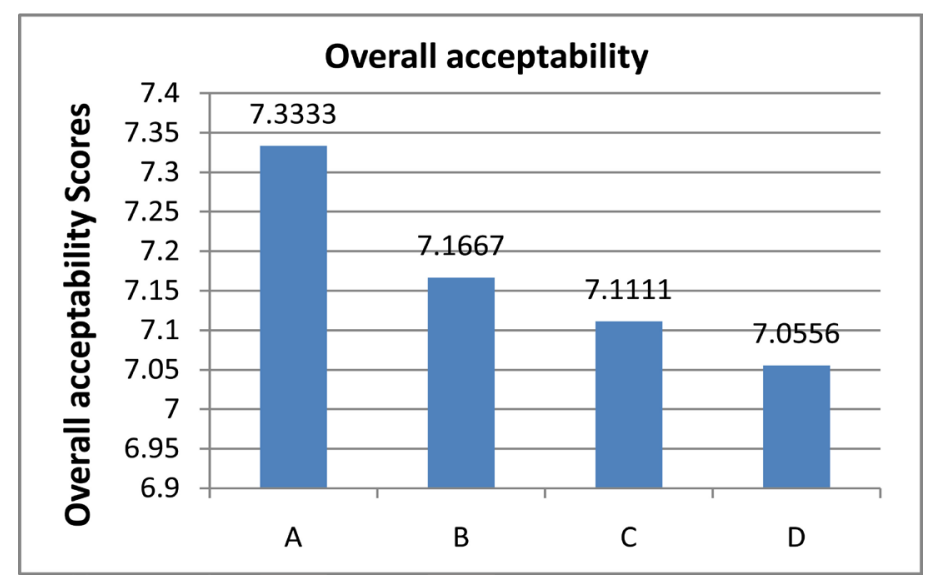

Figure 5. Overall acceptability of roast beef batches. 
an extension of the roast beef shelf life with acceptable organoleptic parameters.

\section{Acknowledgements}

We would like to thank the University of Jordan for their continuous support and financial fund provided to accomplish this research. Thanks, also, to Nabil FactoryAmman/Jordan for their cooperation in providing the necessary facilities.

\section{References}

[1] Toldr, F. and Reig, M. (2011) Innovations for Healthier Processed Meats. Trends in Food Science and Technology, 22, 517-522. http://dx.doi.org/10.1016/j.tifs.2011.08.007

[2] Marco, A., Navarro, L. and Flores, M. (2006) The Influence of Nitrite and Nitrate on Microbial, Chemical and Sensory Parameters of Slow Dry Fermented Sausage. Meat Science, 73, 660-673. http://dx.doi.org/10.1016/j.meatsci.2006.03.011

[3] Honikel, K. (2008) The Use and Control of Nitrate and Nitrite for the Processing of Meat Products. Meat Science, 78, 68-76. http://dx.doi.org/10.1016/j.meatsci.2007.05.030

[4] Cassens, R.G. (1997) Residual Nitrite in Cured Meat. Food Technology, 51, 53-55.

[5] Milkowski, A., Garg, H., Coughlin, J. and Bryan, N. (2010) Nutritional Epidemiology in the Context of Nitric Oxide Biology: A Risk-Benefit Evaluation for Dietary Nitrite and Nitrate. Nitric Oxide, 22, 110-119. http://dx.doi.org/10.1016/j.niox.2009.08.004

[6] Seman, D., Borger, A., Meyer, J., Hall, P. and Milkowski, A. (2002) Modeling the Growth of Listeria monocytogenes in Cured Ready-to-Eat Processed Meat Products by Manipulation of Sodium Chloride, Sodium Diacetate, Potassium Lactate, and Product Moisture Content. Journal of Food Protection, 65, 651-658.

[7] Gill, A. and Holley, R. (2003) Interactive Inhibition of Meat Spoilage and Pathogenic Bacteria by Lysozyme, Nisin and EDTA in the Presence of Nitrite and Sodium Chloride at 24 Degrees C. International Journal of Food Microbiology, 80, 251-259. http://dx.doi.org/10.1016/S0168-1605(02)00171-X

[8] Legan, J., Seman, D., Milkowski, A., Hirschey, J. and Vandeven, M. (2004) Modeling the Growth Boundary of Listeria monocytogenes in Ready-to-Eat Cooked Meat Products as a Function of the Product Salt, Moisture, Potassium Lactate, and Sodium Diacetate Concentrations. Journal of Food Protection, 67, 2195-2204.

[9] USDA (2006) Pathogen Modeling Program (PMP) Version 7. http://ars.usda.gov/Services/docs.htm?docid=6786

[10] Sebranek, J. (2009) Basic Curing Ingredients. In: Tarte, R., Ed., Ingredients in Meat Products, Springer Science + Business Media LLC, New York, 1-24. http://dx.doi.org/10.1007/978-0-387-71327-4_1

[11] Al Marazzeq, K., Haddadin, M., Al Abdullah, B. and Angor, M. (2015) Effect of Nitrite Substitution with Olive Leaves Extract on Color and Sensory Properties of Beef Mortadella. Journal of Agricultural Science, 7, 1-9. http://dx.doi.org/10.5539/jas.v7n12p120

[12] Al-Shuibi, A. and Al-Abdullah, B. (2002) Substitution of Nitrite by Sorbate and the Effect on Properties of Mortadella. Meat Science, 62, 473-478. http://dx.doi.org/10.1016/S0309-1740(02)00041-4

[13] Jin, S. and Park, J. (2013) Effect of the Addition of Schisandra chinensis Powder on the Physico-Chemical Characteristics of Sausage. Asian-Australasian Journal of Animal Science, 26, 1753-1761. http://dx.doi.org/10.5713/ajas.2013.13194

[14] García, M., Beldarraín, T., Fornaris, L. and Díaz, R. (2011) Partial Substitution of Nitrite by 
Chitosan and the Effect on the Quality Properties of Pork Sausages. Ciencia e Tecnologia de Alimentos, 31, 481-487. http://dx.doi.org/10.1590/S0101-20612011000200031

[15] Moarefian, M., Barzegar, M., Sattari, M. and Naghdi Badi, H. (2012) Production of Functional Cooked Sausage by Mentha piperita Essential Oil as a Natural Antioxidant and Antimicrobial Material. Journal of Medicinal Plants, 11, 46-57.

[16] Nascimento, R., Carraro, C., Santos, B., Campagnol, P. and Pollonio, M. (2013) Reducing Salt and Sodium Nitrite in Cooked Turkey Ham: Effect of Celery Extract and Starter Culture on Physicochemical Properties. International Congress of Meat Science and Technology, Izmir, 18-23.

[17] Oiye, S., Konyole, S. and Ngala, S. (2012) Effects of Rosemary Spice (Rosmarinus officinalis L.) and Nitrite Picking Salt Combination on Keeping and Organoleptic Quality of Beef Sausages. Journal of Basic and Applied Scientific Research, 2, 4008-4015.

[18] Oliveira, T., Soares, R., Ramos, E., Cardoso, M., Alves, E. and Piccoli, R. (2011) Antimicrobial Activity of Satureja montana L. Essential Oil against Clostridium perfringens Type A Inoculated in Mortadella-Type Sausages Formulated with Different Levels of Sodium Nitrite. International Journal of Food Microbiology, 144, 546-555.

http://dx.doi.org/10.1016/j.ijfoodmicro.2010.11.022

[19] Honikel, K. (2004) Curing Agents. In: Jensen, W., Devine, C. and Dikeman, M., Eds., Encyclopedia of Meat Sciences, Elsevier, Oxford, 195-201. http://dx.doi.org/10.1016/B0-12-464970-X/00080-5

[20] Maayah, T., Angor, M., Al-Marazeeq, K. and Al-Abdullah, B. (2016) Evaluation of the Shelf Life of Packaged Roast Beef and Some Treatments for Its Extension. Food and Nutrition Science, 7, 205-213. http://dx.doi.org/10.4236/fns.2016.73022

[21] Ham Processing (2004) In Meat Processing. WATT Publishing.

[22] Eber, M. and Muller, W. (1999) Studies on the Suitability of Hampshire Type Meat for Processing Cooked Ham. Fleischwiritschaft International, 1, 19-22.

[23] Fessmann, K. (1996) Smoking Technology at a Time of Change. Fleischwiritschaft International, 75, 32-34.

[24] Berg, H. and Kolar, K. (1991) Evaluation of Rapid Moisture, Fat, Protein and Hydroxyl Proline Determination in Beef and Pork Using the Infratech Food and Feed Analyzer. Fleischwirtschaft International, 71, 787-789.

[25] AOAC (1995) Official Methods of Analysis. 16th Edition, Association of Official Analytical Chemists, Washington DC.

[26] Larmond, E. (1991) Laboratory Methods for Sensory Evaluation of Food. 2nd Edition, Canadian Department of Agriculture Publication, Ottawa.

[27] Littell, R.C., Freund, R.J. and Spector, P.C. (1991) SAS System for Linear Model. 8th Edition, SAS Institute Inc., Cary.

[28] SAS Institute (2007) SAS User's Guide in Statistics. 9th Edition, SAS Institute, Inc., Cary.

[29] Adams, M.R. and Moss, M.O. (2004) Food Microbiology. 2nd Edition, The Royal Society of Chemistry 2000, UK.

[30] Sebranek, J. and Bacus, J. (2007) Cured Meat Products without Direct Addition of Nitrate or Nitrite: What Are the Issues? Meat Science, 77, 136-147. http://dx.doi.org/10.1016/j.meatsci.2007.03.025

[31] Sahoo, J. and Anjaneyulu, S. (1997) Quality Improvement of Ground Buffalo Meat by Preblending and Vacuum Packaging. Fleischwiritschaft International, 1, 15-19.

[32] Carpenter, C.E., Cornforth, D.P. and Whittier, D. (2001) Consumer Preference for Beef 
Colour and Packaging Did Not Affect Eating Satisfaction. Meat Science, 57, 359-363. http://dx.doi.org/10.1016/S0309-1740(00)00111-X

[33] Fernández-López, J., Jiménez, S., Sayas-Barberá, E., Sendra, E. and Pérez-Alvare, J. (2006) Quality Characteristics of Ostrich (Struthio camelus) Burgers. Meat Science, 73, 295-303. http://dx.doi.org/10.1016/j.meatsci.2005.12.011

[34] Froehich, D.A., Gullett, E.A. and Vsborne, W.R. (1983) Effect of Nitrite and Salt on the Color, Flavor and Overall Acceptability of Ham. Journal of Food Science, 48, 152-154. http://dx.doi.org/10.1111/j.1365-2621.1983.tb14811.x

[35] Simon, S., Ellis, D., MacDonald, B., Miller, D., Waldman, R. and Westerberg, D. (1973) Influence of Nitrite and Nitrate Curing Ingredients on Quality of Packaged Frankfurters. Journal of Food Science, 3, 919-923. http://dx.doi.org/10.1111/j.1365-2621.1973.tb02114.x

[36] Sindelar, J. and Milkowski, A. (2011) Sodium Nitrite in Processed Meat and Poultry Meats: A Review of Curing and Examining the Risk/Benefit of Its Use. American Meat Science Association, 1-16. http://www.meatscience.org/SodiumNitriteReview.aspx

[37] Abdullah, B. (2007) Properties of Five Canned Luncheon Meat Formulations. International Journal of Food Science and Technology, 42, 30-35. http://dx.doi.org/10.1111/j.1365-2621.2006.01195.x

[38] Cavestanty, M., Colmenero, F., Solas, M. and Carballo, J. (1994) Incorporation of Sardine Surimi in Bologna Sausage Containing Different Fat Levels. Meat Science, 38, 27-37. http://dx.doi.org/10.1016/0309-1740(94)90093-0

[39] Dave, D. and Ghaly, A. (2011) Meat Spoilage Mechanisms and Preservation Techniques: A Critical Review. American Journal of Agricultural and Biological Sciences, 6, 486-510. http://dx.doi.org/10.3844/ajabssp.2011.486.510

\section{Submit or recommend next manuscript to SCIRP and we will provide best service} for you:

Accepting pre-submission inquiries through Email, Facebook, LinkedIn, Twitter, etc. A wide selection of journals (inclusive of 9 subjects, more than 200 journals)

Providing 24-hour high-quality service

User-friendly online submission system

Fair and swift peer-review system

Efficient typesetting and proofreading procedure

Display of the result of downloads and visits, as well as the number of cited articles

Maximum dissemination of your research work

Submit your manuscript at: http://papersubmission.scirp.org/

Or contact fns@scirp.org 